\title{
Do Places of Delivery Have Contextual Effect on the Perceived Quality of Intrapartum and Postpartum Services? A Multilevel Evidence from Kebumen, Central Java
}

\author{
Helmi Nurlaili'), Didik Tamtomo²), Bhisma Murti1) \\ ${ }^{1)}$ Masters Program of Public Health Science, Universitas Sebelas Maret \\ ${ }^{2)}$ Faculty of Medicine, Universitas Sebelas Maret
}

Background: The maternal mortality rate (MMR) in Indonesia in 2015 was 305 per 100,000 live births. The majority of maternal deaths occur during labor and the puerperium. Increasing access to health services is not enough so that attention is more focused on the quality of services provided. This study aimed to determine the determinants of the quality of childbirth and childbirth by midwives in Kebumen Regency.

Subjects and Method: This study was a cross sectional study at 25 health facilities in Kebumen, Central Java, and was conducted during September-October 2019. The study sample consisted of 200 women giving birth and childbirth selected using the proportionate stratified sampling technique. The dependent variable was the quality of childbirth and childbirth services. The independent variables were age, parity, education, occupation, family income, and type of financing. The data collection was performed using a questionnaire and the data analysis was performed using multilevel multiple linear regression with Stata 13 .

Results: The quality of childbirth and childbirth services increased with maternal age 34 years $(b=$ $1.89 ; 95 \% \mathrm{CI}=0.48$ to $3.31 ; \mathrm{p}=0.009)$, multiparaous $(b=2.20 ; 95 \% \mathrm{CI}=0.78$ to $3.63 ; \mathrm{p}=0.002)$, and type $\mathrm{JKN}$ financing $(\mathrm{b}=0.27 ; 95 \% \mathrm{CI}=-0.94$ to $1.47 ; p=0.659)$. The quality of childbirth and childbirth services decreased with the education of high education $(b=-0.87 ; 95 \% \mathrm{CI}=-\mathbf{2 . 0 2}$ to $0.28 ; \mathrm{p}=0.139)$, working outside the home $(\mathrm{b}=-$ 1.28; $95 \% \mathrm{CI}=-2.64$ to $0.08 ; \mathrm{p}=0.065)$, and family income of $\mathrm{Rp} 1,686,000(\mathrm{~b}=-1.85 ; 95 \% \mathrm{CI}=$ -3.24 to $-0.47 ; \mathrm{p}=0.009$ ). There was a contextual in-fluence of the place of delivery and postpartum on the quality of services received by mothers with $\mathrm{ICC}=51.26 \%$.

Conclusion: The quality of childbirth and childbirth services has improved with the age of 34, multiparous, and JKN types of financing. The quality of childbirth and childbirth services declined with the education of mothers who were high school graduates, working outside the home, and family income of Rp1,686,00o. There is a contextual influence of the place of delivery and postpartum on the quality of service received by the mother.

Keywords: quality of service, childbirth, community health center, multilevel analysis

\section{Correspondence:}

Helmi Nurlaili. Masters Program in Public Health, Universitas Sebelas Maret. Jl. Ir. Sutami 36A, Surakarta 57126, Central Java. Email: helminurlaili@gmail.com. Mobile: 085869950546

Cite this as:

Helmi N, Tamtomo D, Murti B (2020). Do Places of Delivery Have Contextual Effect on the Perceived Quality of Intrapartum and Postpartum Services? A Multilevel Evidence from Kebumen, Central Java. J Health Policy Manage. 5(1): 23-34. https://doi.org/10.26911/thejhpm.2020.05.01.03

Journal of Health Policy and Management is licensed under a Creative Commons Attribution-Non Commercial-Share Alike 4.o International License.

\section{BACKGROUND}

Maternal survival is one of the important issues and has become a global health priority listed in the Sustainable Development Goals (SDGs) in the health sector (Owili et al., 2017). This is in line with the direction of Indonesia's health development, namely the accelerated fulfillment of access to maternal health services through increased delivery of 
assistance by trained health personnel in health facilities (Bappenas, 2014).

World Health Organization (WHO) estimates that in 2015 there were 303,000 mothers in the world died with $99 \%$ of cases occur in low and middle income countries. More than $80 \%$ of cases are preventable deaths (Raven et al., 2012; WHO, 2018a). The maternal mortality rate (MMR) in Indonesia in 2015 was 305 per 100,000 live births (KH), Ministry of Health Republic, 2018). This figure is still far from the global Sustainable Development Goals (SDG's) target of less than 70 per 100,000 KH (BKKBN, 2018).

AKI Central Java in 2017 there were 475 cases or 88.05 per 100,000 KH. AKI of Kebumen Regency has increased since 2014 which was 58.37 per $100,000 \mathrm{KH}$ to 80.01 per 100,000 KH in 2016 (Central Java Health Office, 2018; Kebumen Health Office, 2017).

Direct factors causing maternal death are bleeding (44\%), eclampsia (21\%), pulmonary edema (14\%), and other factors (21\%). While the indirect factor is the lack of access to quality maternal health services, especially emergency services. This is caused by being late in recognizing danger signs, making decisions, reaching health facilities, and getting adequate health services (Health Office, Kebumen, 2017).

The majority of maternal deaths occur during labor and the puerperium. More than 40 percent of cases during labor occur due to direct causes. As many as 45 percent of cases in the puerperium occur in the first 24 hours after delivery (Brenner et al., 2015; Owili et al., 2017). Labor and childbirth periods are very important for the survival of the mother and baby because the risk of morbidity and mortality can increase significantly if complications arise. The delivery period is relatively short so that the quality of delivery services is seen in the puerperium (Merdad and Ali, 2018; WHO, 2018b).
In addition to routine antenatal care (ANC) examinations, the presence of skilled birth attendants during childbirth and obstetric emergencies is a strategy to reduce MMR (Merdad and Ali, 2018). The Ministry of Health's strategic plan for 2015-2019 establishes childbirth in a health care facility as an indicator of maternal health efforts. The existence of life-saving equipment and hygienic labor conditions will help mothers and their babies avoid the risk of complications (BKKBN, 2018; Ministry of Health, 2018).

Improving access to childbirth services does not always guarantee quality obstetric services and better survival. Therefore, attention is more focused on the quality of care for mothers and newborns (Owili et al., 2017). In addition to routine services, emergency services also need to be improved because obstetric complications cannot be predicted and occur in all health facilities. Thus, health workers can prevent, identify and manage various complications (Miltenburg et al., 2018; Raven et al., 2012). The quality of childbirth and childbirth services is assessed from several aspects, namely patient safety, timeliness, effectiveness, efficiency, fairness, patient centeredness, empathy, resources, and types of health facilities (Mosadeghrad, 2012; WHO, 2016).

Authors are interested in examining the determinants of the quality of childbirth and childbirth by midwives in Kebumen Regency.

\section{SUBJECTS AND METHOD}

\section{Study Design}

This study was an observational analytic using cross sectional design in 25 health facilities in Kebumen Regency, Central Java, September until October 2019.

\section{Population and Sample}

The source population is maternity and postpartum mothers in 25 Kebumen District health facilities. 200 maternity and postpar- 
tum mothers were selected using proportionate stratified sampling.

\section{Study Variables}

The dependent variable is the quality of childbirth and childbirth services. The independent variables include age, parity, education, occupation, family income, and type of financing.

\section{Operational Definition of Variables} The quality of childbirth and childbirth services is a measure of the extent to which a delivery and childbirth service can meet the needs of patients. The measuring instrument used was a questionnaire. The scale of the data was continuous and for analysis purposes the data was converted into a dichotomy. Age is the time (year) from the birth of the study subject as stated on id card until the study was conducted. The measuring instrument used was a questionnaire. The scale of the data was continuous, and for analytical purposes, the data was converted into a dichotomy.

Parity is the number of births that have ever been experienced by subjects. The measuring instrument used was a questionnaire. The scale of the data was continuous, and for analytical purposes, the data was converted into a dichotomy.

The level of education is the level of formal education that has been taken by study subjects based on the last diploma obtained. The measuring instrument used was a questionnaire. The scale of the data was categorical. Occupation is an activity carried out every day by subjects. The measuring instrument used was a questionnaire. The scale of the data was categorical.

Family income is the total income obtained by family members through work with an average monthly income in the last six months. The measuring instrument used was a questionnaire. The scale of the data was continuous, and for analytical purposes, the data was converted into a dichotomy.
Type of financing is the participation of study subjects in the guarantee of health financing. The measuring instrument used was a questionnaire. The scale of the data was categorical.

Type of health facility is a place for study subjects to get delivery and childbirth services. The types of health facilities in this study are Puskesmas and Midwife Independent Practices. The measuring instrument used was a questionnaire. The scale of the data was categorical.

\section{Data Analysis}

Univariate analysis was carried out to explain the characteristics of each study variable presented with frequency and percentage. Bivariate analysis explains the effect of one independent variable on a dependent variable using the chi-square test with a 95\% confidence level. Multivariate analysis explains the effect of more than one independent variable on one dependent variable using multilevel multiple linear regression.

\section{Research Ethic}

Research ethics consists of informed consent, anonymity, and confidentiality. The ethical feasibility of this study came from the Ethical Commission on Health Research from the Surakarta General Hospital in Moewardi Region with the number: 1.032 / VIII / HREC / 2019.

\section{RESULTS}

\section{Sample Characteristics}

Table 1 shows the characteristics of continous data subjects. Meanwhile, table 2 shows the characteristics of categorical data subjects. 109 mothers aged $\geq 34$ years (54.5\%), 114 multiparous mothers (57.0\%), 103 mothers with education < senior high school (51.5\%), 117 mothers working at home (58.5\%), and 119 mothers with family opinions $<\mathrm{Rp}$ $1,686,000$ (59.5\%). Mothers who used this type of National Health Insurance (JKN) financing were 134 respondents (67.0\%). 
Nurlaili et al./ Do Places of Delivery Have Contextual Effect on the Perceived

Table 1. Sample Characteristics of continuous data subjects

\begin{tabular}{llllll}
\hline Variable & N & Mean & SD & Min. & Max. \\
\hline Age (year) & 200 & 33.15 & 5.59 & 21 & 49 \\
Parity & 200 & 1.73 & 0.74 & 1 & 4 \\
Income (Rupiah) & 200 & 1.638 .780 & 643.510 & 600.000 & 4.300 .000 \\
Quality of service & 200 & 43.55 & 6.67 & 23 & 54 \\
\hline
\end{tabular}

Table 2. Characteristics of categorical data subjects

\begin{tabular}{lcc}
\hline \multicolumn{1}{c}{ Variable } & $\mathbf{n}$ & $\mathbf{\%}$ \\
\hline Age & & \\
$<34$ years & 91 & 45.5 \\
$\geq 34$ years & 109 & 54.5 \\
Parity & & \\
Primiparous & 86 & 43.0 \\
Multiparous & 114 & 57.0 \\
Education & & \\
< SHS & 103 & 51.5 \\
$\geq$ SHS & 97 & 48.5 \\
Occupation & & \\
Working at home & 117 & 58.5 \\
Working outside of home & 83 & 41.5 \\
Family Income & & \\
$<$ Rp 1,686,ooo & 119 & 59.5 \\
$\geq$ Rp 1,686,ooo & 81 & 40.5 \\
Type of financing & & \\
General & 66 & 33.0 \\
QKN & 134 & 67.0 \\
Poor & & \\
Good & 98 & 49.0 \\
\hline
\end{tabular}

\section{The result of bivariate analysis}

Table 3 shows the bivariate analysis of the effect of a independent variable on a dependent variable. The quality of childbirth and childbirth services improved with mothers aged $\geq 34$ years $(\mathrm{OR}=31.18 ; 95 \% \mathrm{CI}=14.25$ to 68.26; $\mathrm{p}<0.001$ ), multiparaous ( $\mathrm{OR}=31.78$; 95\% $\mathrm{CI}=14.18$ to $71.22 ; \mathrm{p}<0.001)$, and type of $\mathrm{JKN}$ financing $(\mathrm{OR}=2.69 ; 95 \% \mathrm{CI}=1.46$ to 4.95; $\mathrm{p}=0.001)$. The quality of childbirth and childbirth services decreases with maternal education $\geq$ Senior high school $(\mathrm{OR}=0.12$; $95 \% \mathrm{CI}=0.06$ to $0.22 ; \mathrm{p}<0.001)$, work outside the home $(\mathrm{OR}=0.09 ; 95 \% \mathrm{CI}=0.04$ to 0.17 ; p <0.001), and family income $\geq$ $\mathrm{Rp} 1,686,000(\mathrm{OR}=0.04 ; 95 \% \mathrm{CI}=0.02$ to $0.08 ; \mathrm{p}<0.001)$.

\section{The result of multilevel analysis}

Table 4 shows the results of the multilevel multiple linear regression analysis. There is a relationship between maternal age and the assessment of the quality of delivery and childbirth services. Mothers aged $\geq 34$ years gave a value of health service quality 1.89 units higher than mothers aged $<34$ years $(b=1.89 ; 95 \% \mathrm{CI}=0.48$ to $3.31 ; \mathrm{p}=0.009)$. There was a relationship between maternal parity and assessment of quality of delivery services and puerperal. Multiparous mothers gave a quality value of health services 2.20 units higher than Primiparous mothers $(\mathrm{b}=$ $2.20 ; 95 \% \mathrm{CI}=0.78$ to $3.63 ; \mathrm{p}=0.002)$. 
Nurlaili et al./ Do Places of Delivery Have Contextual Effect on the Perceived

There is a relationship between maternal education and the assessment of the quality of childbirth and childbirth services, although it is not statistically significant. Mothers with education $\geq$ Senior high school gave a quality value of health services 0.87 units lower than mothers who were educated $<$ high school $(\mathrm{b}=0.87 ; 95 \% \mathrm{CI}=-2.02$ to o.28; $\mathrm{p}=0.139$ ).

There is a relationship between mother's work and the assessment of the quality of childbirth and childbirth services. Mothers who worked outside the home gave 1.28 units lower quality of health services than mothers who worked inside the home $(b=-1.28 ; 95 \%$ $\mathrm{CI}=-2.64$ to 0.08 ; $\mathrm{p}=0.065$ ).

There is a relationship between maternal family income with an assessment of the quality of childbirth and childbirth services. Mothers with family income $\geq \mathrm{Rp} 1,686,000$ gave a value of health service quality of 1.85 units lower than mothers with family income $<\mathrm{Rp} 1,686,000(\mathrm{~b}=-1.85 ; 95 \% \mathrm{CI}=-3.24$ to $0.47 ; \mathrm{p}=0.009$ ).

There is a relationship between the types of financing used by mothers and the assessment of the quality of childbirth and childbirth services, although not statistically significant. Mothers who used JKN financing gave a quality value of 0.27 health services higher than those who used general financing $(b=0.27 ; 95 \% \mathrm{CI}=-0.94$ to $1.47 ; \mathrm{p}=0.659)$.

There is a contextual effect of the delivery and childbirth place on the quality of childbirth and childbirth services received by mothers with ICC $=51.26 \%$.

Table 3. Bivariate analysis with chi-square test about determinants of quality assessment of childbirth and childbirth services

\begin{tabular}{|c|c|c|c|c|c|c|c|c|c|c|}
\hline \multirow{3}{*}{$\begin{array}{l}\text { Independent } \\
\text { Variables }\end{array}$} & \multicolumn{4}{|c|}{ Quality of Service } & \multirow{2}{*}{\multicolumn{2}{|c|}{ Total }} & \multirow{3}{*}{ OR } & \multicolumn{2}{|c|}{ (95\%) CI } & \multirow{3}{*}{$\mathbf{p}$} \\
\hline & \multicolumn{2}{|c|}{ Poor } & \multicolumn{2}{|c|}{ Good } & & & & Lower & Upper & \\
\hline & $\mathbf{n}$ & $\%$ & $\mathbf{n}$ & $\%$ & $\mathbf{n}$ & $\%$ & & Limit & Limit & \\
\hline \multicolumn{11}{|l|}{ Age } \\
\hline$<34$ years & 79 & 86.8 & 12 & 13.2 & 91 & 100 & 31.18 & 14.25 & 68.26 & $<0.001$ \\
\hline$\geq 34$ years & 19 & 17.4 & 102 & 82.6 & 109 & 100 & & & & \\
\hline \multicolumn{11}{|l|}{ Parity } \\
\hline Primiparous & 76 & 88.4 & 10 & 11.6 & 86 & 100 & 31.78 & 14.18 & 71.22 & $<0.001$ \\
\hline Multiparous & 22 & 19.3 & 92 & 80.7 & 114 & 100 & & & & \\
\hline \multicolumn{11}{|l|}{ Education } \\
\hline$<$ SHS & 26 & 25.2 & 77 & 74.8 & 103 & 100 & 0.12 & 0.06 & 0.22 & $<0.001$ \\
\hline$\geq$ SHS & 72 & 74.2 & 25 & 25.8 & 97 & 100 & & & & \\
\hline \multicolumn{11}{|l|}{ Occupation } \\
\hline Working at home & 31 & 26.5 & 86 & 73.5 & 117 & 100 & 0.09 & 0.04 & 0.17 & $<0.001$ \\
\hline Working outside & 67 & 80.7 & 16 & 19.3 & 83 & 100 & & & & \\
\hline \multicolumn{11}{|l|}{ Family Income } \\
\hline$<\operatorname{Rp} 1,686,000$ & 26 & 21.8 & 93 & 78.2 & 119 & 100 & 0.04 & 0.02 & 0.08 & $<0.001$ \\
\hline$\geq \mathrm{Rp} 1,686,000$ & 72 & 88.9 & 9 & 11.1 & 81 & 100 & & & & \\
\hline \multirow{2}{*}{\multicolumn{11}{|c|}{$\begin{array}{l}\text { Type of } \\
\text { financing }\end{array}$}} \\
\hline & & & & & & & & & & \\
\hline General & 43 & 65.2 & 23 & 34.8 & 66 & 100 & 2.69 & 1.46 & 4.95 & 0.001 \\
\hline JKN & 55 & 41.0 & 79 & 59.0 & 134 & 100 & & & & \\
\hline
\end{tabular}


Nurlaili et al./ Do Places of Delivery Have Contextual Effect on the Perceived

Table 4. Multilevel multiple linear regression analysis of the determinants of the quality of childbirth and childbirth services

\begin{tabular}{|c|c|c|c|c|}
\hline \multirow{2}{*}{ Independent Variable } & \multirow{2}{*}{ b } & \multicolumn{2}{|c|}{$95 \% \mathrm{CI}$} & \multirow[b]{2}{*}{$\mathbf{p}$} \\
\hline & & Lower Limit & Upper Limit & \\
\hline \multicolumn{5}{|l|}{ Fixed effect } \\
\hline Age $\geq 34$ years & 1.89 & 0.48 & $3 \cdot 31$ & 0.009 \\
\hline Multiparous & 2.20 & 0.78 & 3.62 & 0.002 \\
\hline Education ( $\geq$ SHS) & -0.87 & -2.02 & 0.28 & 0.139 \\
\hline Working outside of home & -1.28 & -2.64 & 0.08 & 0.065 \\
\hline Family Income ( $\geq$ Rp1,686,00o) & -1.85 & -3.24 & -0.47 & 0.009 \\
\hline JKN financing type & 0.27 & -0.94 & 1.47 & 0.659 \\
\hline \multicolumn{5}{|l|}{ Random effect } \\
\hline \multicolumn{5}{|l|}{ Type of service facility } \\
\hline $\begin{array}{l}\text { Var (konstanta) } \\
\text { n observation }\end{array}$ & $\begin{array}{c}13.14 \\
200\end{array}$ & 6.90 & 25.01 & \\
\hline $\mathrm{p}$ & $<0.001$ & & & \\
\hline Intraclass Correlation (ICC) & $51.26 \%$ & & & \\
\hline
\end{tabular}

\section{DISCUSSION}

1. The effect of age on the quality of childbirth and childbirth services

The analysis showed that there was a relationship between maternal age and the assessment of the quality of childbirth and postpartum care. 34-year-old mothers give 1.89 units higher quality of health services than mothers aged $<34$ years.

Grøndahl et al. (2011) explained that age had a significant effect on the quality of health services. Older patients have more realistic life experiences and expectations. They feel they can appreciate the service they get more.

The older the patient the better the assessment of service quality. They are generally more open so that expectations for services received are not too high compared to younger ones (Sulistyo et al., 2019).

\section{The effect of parity on the quality of childbirth services}

The analysis showed that there was a relationship between maternal parity with an assessment of the quality of childbirth and childbirth services. Multipara mothers give a value of 2.20 units of quality health services higher than primipara mothers.
Cooke and Stacey (2003) and Fenwick et al. (2010) explained that multiparous women rated service quality more positively than primipara. Mothers who deliver a second or more babies do not need much help, support, and/ or guarantees, although often there are still traumatic problems from previous deliveries such as breastfeeding.

Primiparous mothers tend to be worried and always pay attention to every service process they receive. They expect to get the best service according to their knowledge and information. However, this first delivery has not provided experience related to things that are less comfortable. This causes them to assess the quality obtained is not good (Maulana, 2012).

\section{The effect of education level on the quality of childbirth and childbirth services}

The analysis showed that there was a relationship between the level of maternal education and the assessment of the quality of childbirth and childbirth services, although it was not statistically significant. Mothers with a high school education rate the quality of health services 0.87 units lower than mothers with a high school education. 
Widayati et al. (2017) explains the higher the level of patient education, the lower the quality of health service assessment. Higher educated patients have higher expectations and standards for the quality of health services. They are more critical in assessing the quality of health services because they have experience based on their education.

Patients who are unable to read and write have a better perception of the quality of nursing services than patients with tertiary education. Highly educated patients expect high standards of service based on their knowledge and awareness of the services obtained (Dikmen and Yilmaz, 2016; Kewi et al., 2018).

\section{The effect of work on the quality of childbirth and childbirth services}

The analysis showed that there was a relationship between mother's work and the assessment of the quality of childbirth and childbirth services. Mothers who work outside the home rate 1.28 units lower than the quality of those who work at home.

Utami et al. (2017) explained that there was a negative influence between the status of work and the assessment of the quality of services received. Patients who work have more expectations and tend to give less assessment of the services received. They get more information than those who do not work.

Individuals who work outside the home always focus on work and get the services needed. They tend to be very dependent on health services. Conversely, those who work at home tend to be independent of their health (Sulistyo et al., 2019).

\section{The effect of family income on the quality of childbirth and childbirth services}

The analysis shows that there is a relationship between the income of the mother's family with an assessment of the quality of delivery and childbirth services. Mothers with family income of $\mathrm{Rp}$ 1,686,000 give a value of health service quality of 1,85 units lower than mothers with family income $<\mathrm{Rp} 1,686,000$.

Widayati et al. (2017) explain that family income negatively influences the quality of health services. The higher the patient's income, the greater the expectations for health workers in providing quality services. Therefore, perceptions of the quality of health services will tend to be lower. Patients with higher incomes demand quality services. They are able and willing to pay a number of costs if the quality service must be obtained through payment of a fee.

Patients with $<$ minimum wage income tend to give good assessments of health services. With high incomes, they also choose high expectations for the quality of service received based on health awareness (Utami et al., 2017).

\section{The effect of the type of financing on the quality of childbirth services}

The analysis shows that there is a relationship between the types of financing and the assessment of the quality of childbirth and childbirth services, although it is not statistically significant. Mothers who use JKN financing give a quality value of 0.27 health units higher than mothers who use general financing.

These results are different from the study of Duku et al. (2018) and Fenenga et al. (2014) which states that insurance status is significantly negatively related to the perception of the quality of health services. Patients with health insurance assess lower quality of health services. They expressed dissatisfaction with the length of waiting time, inadequate information availability, unfair queuing system, poor attitude of staff, and poor quality of drugs.

$\mathrm{JKN}$ is a compulsory social health insurance. This principle aims to protect all people and meet the basic needs of adequate public health. JKN membership is divided into recipients of contribution assistance (PBI) 
and not PBI (Kemenkes RI, 2013). Mothers with JKN or public financing get fair delivery and childbirth services as needed. Those with JKN financing, especially PBI participants, felt more satisfied with the quality of service received. Without spending a fee, they receive delivery and childbirth services the same as mothers who pay JKN contributions or general financing. In addition, childbirth services are actions that must be immediately given to pregnant women with signs of childbirth. In contrast to other health services, labor can be given without waiting in line, whether they are with insurance or general financing.

These results are in line with the systematic review by Spaan et al. (2012) which states that there is a positive effect of health insurance on service quality through increasing the availability of essential medicines and the short waiting time. The inclusion of health insurance can provide financial protection in reducing spending and increasing the utilization of inpatient and outpatient services. In the aspect of social inclusion, health insurance has a positive impact through patterns of registration and utilization for vulnerable groups, such as the poor.

\section{The effect of contextual health facili- ties on the quality of childbirth ser- vices}

The analysis showed that there was a contextual effect of the delivery and childbirth place on the quality of delivery and childbirth services received by mothers with $\mathrm{ICC}=51.26 \%$.

Physical resources are the dominant aspect of assessing the quality of health services. The availability of facilities and the environment are the main factors that affect the quality of service from the patient's side. Lack of patient knowledge about the technical aspects of health care makes them generalize service quality in tangible aspects (Mosadeghrad, 2012).

Puskesmas is a government-owned health facility. The source of funding comes from the Regional Budget (APBD) and the National Budget (APBN), whose management is regulated by statutory provisions. While the Midwife Independent Practice $(\mathrm{PMB})$ is a place for individual midwifery services whose management is the responsibility of the owner (Ministry of Health, 2014; Ministry of Health, 2017). Some mothers feel uncomfortable while in the puskesmas because of the lack of curtains in the delivery room, the absence of puerperal space in several puskesmas, the number of mosquitoes, and the presence of cockroaches in the toilet.

Study by Fisseha et al. (2019) in 32 health facilities explained that mothers who received friendly services during childbirth were likely to get quality services. This is related to the lack of skills and competence of midwives. The lack of skilled midwives, high workloads, and poor job satisfaction can also cause poor service quality.

Puskesmas services cover communities in one district. In addition to providing Public Health Efforts (UKM) and Individual Health Efforts (UKP) services, midwives at the Puskesmas also collaborate with service networks and health service facility networks in the region, including village midwives and PMB (Ministry of Health, 2014). Staff or employees with excessive workloads will reduce productivity and quality of work. The possibility of carrying out the work becomes not timely, unsatisfactory, and results in disappointment with the expected results (Melati et al., 2015).

The results of this study are supported by Fenwick et al. (2010) regarding mothers' perceptions of the style and quality of midwifery services during the early post-partum period at the hospital and at home. Mothers who get services at home have a better perception than hospital services. Services in hospitals are considered chaotic because of inconsistent advice. The high number of patients causes the workload of midwives to 
Nurlaili et al./ Do Places of Delivery Have Contextual Effect on the Perceived

be higher so that midwives are difficult to find. There are only a few midwives who are considered to have empathy by being willing to listen to mothers' complaints.

\section{AUTHOR CONTRIBUTION}

Helmi Nurlaili, lead author, plays a role in collecting and processing study data. Didik Tamtomo examines the conceptual framework and study methods. Bhisma Murti reviewed the study paper.

\section{CONFLICT OF INTEREST}

There are no conflicts of interest

\section{FUNDING AND SPONSORSHIP}

This study is self-funded.

\section{ACKNOWLEDGEMENT}

The author would like to thank the Puskesmas, the Midwife Independent Practice (PMB), and the subjects for agreeing to be subjects.

\section{REFERENCE}

Badan Kependudukan dan Keluarga Berencana Nasional, Badan Pusat Statistik, Kementerian Kesehatan, USAID (2018). Survei demografi dan kesehatan Indonesia 2017 (Indonesia demographic and health survey 2017). Jakarta: Badan Pusat Statistik. Retrieved from http://sdki.bkkbn.go.id/files/buku/2o17IDHS.pdf

Badan Perencanaan Pembangunan Nasional (National Development Planning Agency) (2014). Lampiran Peraturan Presiden Republik Indonesia Nomor 2 Tahun 2015 tentang Rencana pembangunan jangka menengah nasional 20152019: Buku 1 Agenda pembangunan nasional (Attachment of Republic of Indonesia Presidential Regulation Number 2 Year 2015 concerning the National Medium-term Development Plan 2015-2019: Book 1 National Develop- ment Agenda). Jakarta: Badan Perencanaan Pembangunan Nasional. Retrieved from https://www.bappenas.go.id/id/data-dan-informasi-utama/dokumen-perencanaan-dan-pelaksanaan/dokumen-rencana-pembangunan-nasional/rpjp-2005-2025/rpjmn2015-2019/

Brenner S, De Allegri M, Gabrysch S, Chinkhumba J, Sarker M, Muula AS (2015). The quality of clinical maternal and neonatal healthcare - a strategy for identifying 'routine care signal functions'. PLoS ONE, 10(4): 1-19. https://doi.org/10.1371/journal.pone.0123968

Cooke M, Stacey T (2003). Differences in the evaluation of postnatal midwifery support by multiparous and primiparous women in the first two weeks after birth. Aust J Midwifery, 16(3): 18-24. https://doi.org/10.1016/S1448-8272(03)800123

Dikmen Y, Yilmaz D (2016). Patient's perceptions of nursing care-a descriptive study from Turkey. Ann Nurs Pract, 3(3): 1-5. Retrieved from https://pdfs.semanticscholar.org/1c5c/ee1c3fea9gf 9f5c1d2a32baca4d563da40aa.pdf?_ga= 2.132673865.639007902.1574343351-2 093509220.1574085485

Dinas Kesehatan Kabupaten Kebumen (Kebumen District Health Office) (2017). Profil Kesehatan Kabupaten Kebumen 2016 (Kebumen District Health Profile 2016). Kebumen: Dinas Kesehatan Kabupaten Kebumen. Retrieved from https://www.depkes.go.id/resources/download/profil/PROFIL_KAB_ KOTA_2016/3305_Jateng_Kab_Kebu men_2016.pdf

Dinas Kesehatan Provinsi Jawa Tengah (Central Java Provincial Health Office) (2018). Profil Kesehatan Provinsi Jawa Tengah tahun 2017 (Health Profile of Central Java Province in 2017). 
Nurlaili et al./ Do Places of Delivery Have Contextual Effect on the Perceived

Semarang: Dinas Kesehatan Provinsi Jawa Tengah. Retrieved from http://dinkesjatengprov.go.id/v2018/dokumen/profil_2018/files/downloads/P rofil\%2OJateng\%202018\%20cetak.pdf

Duku SKO, Nketiah-Amponsah E, Janssens W, Pradhan M (2018). Perceptions of healthcare quality in Ghana: Does health insurance status matter? PLoS ONE, 13(1): 1-17. https://doi.org/10. 1371/journal.pone.0190911

Fenenga CJ, Boahene K, Arhinful D, de Wit TR, Hutter I (2014). Do prevailing theories sufficiently explain perceptions and health-seeking behavior of Ghanaians? Int J Health Plann Mgmt, 29: 2642. https://doi.org/10.10hpm.2159.

Fenwick J, Butt J, Dhaliwal S, Hauck Y, Schmied V (2010). Western Australian women's perceptions of the style and quality of midwifery postnatal care in hospital and at home. Women and Birth, 23: 10-21. https://doi.org/10.1016/j.wombi.2009.06.001

Fisseha G, Berhane Y, Worku A (2019). Quality of intrapartum and newborn care in Tigray, Northern Ethiopia. BMC Pregnancy and Childbirth, 19(37): 1-8. https://doi.org/10.1186/s12884-0192184-z

Grøndahl VA, Karlsson I, Hall-Lord ML, Appelgren J, Wilde-Larsson B (2011). Quality of care from patients' perspective: impact of the combination of person-related and external objective care conditions. J. Clin. Nurs. 20: 25402551.https://doi.org/10.111/j.1365-2702.2011.03810.x

Ministry of Health RI (2013). Buku pedoman sosialisasi Jaminan Kesehatan Nasional (JKN) dalam Sistem Jaminan Sosial Nasional (Handbook on the socialization of the National Health Insurance (JKN) in the National Social Security System). Jakarta: Kemenkes RI. Retrie- ved from https://www.academia.edu/33747042/BUKU_PEGANGAN_SOSIALISASI

Ministry of Health RI (2014). Peraturan Menteri Kesehatan Republik Indonesia Nomor 75 Tahun 2014 tentang Pusat Kesehatan Masyarakat (Regulation of the Minister of Health of the Republic of Indonesia Number 75 of 2014 concerning Community Health Centers). Jakarta: Kementerian Kesehatan Republik Indonesia. Retrieved from https://puskesmas.bantulkab.go.id/piyungan/files/2014/11/PermenkesNo-75-Th-2014-ttg-Puskesmas1.pdf

Ministry of Health RI (2017). Peraturan Menteri Kesehatan Republik Indonesia Nomor 28 Tahun 2017 tentang Izin dan penyelenggaraan praktik bidan (Regulation of the Minister of Health of the Republic of Indonesia Number 28 Year 2017 regarding Licensing and implementation of midwife practices). Jakarta: Kementerian Kesehatan Republik Indonesia. Retrieved from http://www.ibi.or.id/media/PMK\%20No.\%2028\%20ttg\%20Izin\%20dan\%20Penyelenggaraan\%2oPraktik\%2oBidan.pdf

Ministry of Health RI (2018). Profil kesehatan Indonesia tahun 2017 (Indonesia's health profile in 2017). Jakarta: Kementerian Kesehatan Republik Indonesia. Retrieved from https://www.kemkes.go.id/resources/download/pusdatin/profil-kesehatan-indonesia/Profil-Kesehatan-Indonesia-tahun-2017.pdf

Kewi SY, Tesema AA, Negussie BB (2018). Patient's perception towards quality of nursing care in inpatient department at public hospitals of Benishangul Gumuz Regional State, North West Ethiopia. J Nurs Care. 7(4): 1-10. https://doi.org/10.4172/2167-1168.1000467 
Nurlaili et al./ Do Places of Delivery Have Contextual Effect on the Perceived

Maulana (2012). Penilaian kepuasan ibu hamil terhadap mutu layanan antenatal dalam kaitannya dengan kepatuhan dan karakteristik bidan di Puskesmas se Kota Jambi tahun 2011 (Assessment of the satisfaction of pregnant women with the quality of antenatal services in relation to compliance and characteristics of midwives in Puskesmas throughout Jambi City in 2011). Depok: Universitas Indonesia. Retrieved from http://lontar.ui.ac.id/file?file $=$ digital $/ 20315224-T 31920-P e n i l a i-$ an\%2okepuasan.pdf

Melati KYA, Wigati PA, Arso SP (2015). Analisis beban kerja bidan desa di Puskesmas Duren Kabupaten Semarang (Analysis of village midwife workload in Puskesmas Duren, Semarang Regency). JKM, 3(3): 30-40. Retrieved from https://ejournal3.undip.ac.id/index.php/jkm/article/download/12039/11692

Merdad L, Ali MM (2018). Timing of maternal death: levels, trends, and ecological correlates using sibling data from 34 sub-Saharan African countries. PLoS ONE, 13(1): 1-13. https://doi.org/10.1371/journal.pone.0189416.

Miltenburg AS, Kiritta RF, Meguid T, Sundby $\mathrm{J}$ (2018). Quality of care during childbirth in Tanzania: identification of areas that need improvement. Reproductive Health, 15(14): 1-12. https://doi.org/10.1186/s12978-018-0463-1.

Mosadeghrad AM (2012). A conceptual framework for quality of care. Mater Sociomed, 24(4): 251-261. https://doi.org/10.5455/msm.2012.24.251-261.

Owili PO, Muga MA, Mendez BR, Chen B (2017). Quality of maternity care and its determinants along the continuum in Kenya: A structural equation modeling analysis. PLoS ONE, 12(5): 1-15. https://doi.org/10.1371/journal.pone.0177756

Raven JH, Tolhurst RJ, Tang S, van den Broek $N$ (2012). What is quality in maternal and neonatal health care?. Midwifery, 28: e676-e683. https:// doi.org/10.1016/j.midw.2011.09.003

Spaan E, Mathijssen J, Tromp N, McBain F, Have At, Baltussen R (2012). The impact of health insurance in Africa and Asia: a systematic review. Bull World Health Organ, 90: 685-692A. https://doi.org/10.2471/BLT.12.102301.

Sulistyo SA, Tamtomo D, Sulaeman ES (2019). Accreditation status and other factors affecting patient satisfaction in hospital. J Health Policy Manage, 4(3): 139-149. https://doi.org/10.26911/the jhpm.2019.04.03.01.

Utami YT, Tamtomo D, Sulaeman ES (2017). Patient characteristics, finan-cing type, accreditation status, and quality of health services at community health center, Surakarta. J Health Policy Manage, 2(1): 79-90. https://doi.org/10.26911/thejhpm.2017.01.02.07\%20\%20\%20

World Health Organization (2016). Standards for improving quality of maternal and newborn care in health facilities. Genewa: World Health Organization. Retrieved from https://www.who.int/maternal_child_adolescent/documents /improving-maternal-newborn-carequality/en/

World Health Organization (2018a). World health statistics 2018: Monitoring health for the SDGs, Sustainable Development Goals. Geneva: World Health Organization. Retrieved from https://www.who.int/gho/publications/world_health_statistics/2018/en/

World Health Organization (2018b). WHO recommendations: Intrapartum care for a positive childbirth experience. 
Nurlaili et al./ Do Places of Delivery Have Contextual Effect on the Perceived

Geneva: World Health Organization.

Retrieved from https://www.who.int/reproductivehealth/publications- /intrapartum-care-guidelines/en/nsert your text here 